\title{
Comparison of thiol/disulphide homeostasis with modified Alvarado and RIPASA scores in the diagnosis of acute appendicitis
}

\author{
Servan Gökhan, M.D., ${ }^{1}$ IIsmail Erkan Aydın, M.D., ${ }^{2}$ ๑ Gül Pamukçu Günaydın, M.D., ${ }^{1}$

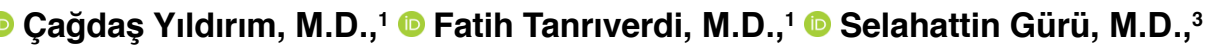 \\ Fatih Ahmet Kahraman, M.D., ${ }^{1}$ 을 Özan Erel, M.D. ${ }^{4}$
}

${ }^{1}$ Department of Emergency Medicine, Yıldırım Beyazıt University Faculty of Medicine, Ankara-Turkey

${ }^{2}$ Department of Emergency Medicine, Çankırı State Hospital, Çankırı-Turkey

${ }^{3}$ Department of Emergency Medicine, Bilkent City Hospital, Ankara-Turkey

${ }^{4}$ Department of Biochemistry, Yıldırım Beyazıt University Faculty of Medicine, Ankara-Turkey

\begin{abstract}
BACKGROUND: This study aims to investigate the role of thiol/disulfide homeostasis parameters in the diagnosis of acute appendicitis and to determine whether it is beneficial to use these parameters in combination with the modified Alvarado and RIPASA scoring systems.
\end{abstract}

METHODS: This study was prospectively carried out on 265 patients who presented to the emergency department with the complaint of right lower quadrant pain between 01.07 .2017 and 31.12.2017, and met the inclusion criteria of this study. Oxidative stress markers were evaluated on two groups. The relationship between these parameters and the modified Alvarado and RIPASA scoring systems was analyzed.

RESULTS: The mean levels of disulfide, disulfide/native thiol and disulfide/total thiol were found to be significantly higher in the appendicitis group $(p<0.00 I)$. The mean levels of native thiol, total thiol and native thiol/total thiol were significantly lower in the same group ( $\mathrm{p}<0.00 \mathrm{I}, 0.00 \mathrm{I}$ and 0.007 , respectively). The mean levels of disulfide, disulfide/native thiol and disulfide/total thiol were recorded to be significantly higher in the high-risk group according to the results of RIPASA ( $\mathrm{P}=0.016,0.003$ and $0.00 \mathrm{I}$, respectively).

CONCLUSION: Thiol/disulfide homeostasis parameters can be used with the modified Alvarado and RIPASA scoring systems in the diagnosis of acute appendicitis.

Keywords: Acute appendicitis; modified Alvarado and RIPASA; thiol/disulfide homeostasis.

\section{INTRODUCTION}

Acute appendicitis is the most common cause in abdominal pain cases presenting to the emergency department and requiring urgent surgical interventions. Acute appendicitis is a medical emergency that may progress to a series of complications, such as peritonitis, or even result in death unless it is treated. ${ }^{[1,2]}$ The incidence of acute appendicitis is approximately $6-8 \%$ in both western and eastern societies for a life-long period. ${ }^{[3-5]}$ Although it is seen only in approximately $10 \%$ of the general population, there are certain diagnostic difficulties, and the negative appendectomy rates may exceed $15-20 \%$ in many centers. ${ }^{[6,7]}$ Acute appendicitis is an acute inflammatory condition of the appendiceal tissues that is characterized by the increased mucosal barrier permeability and luminal obstruction. ${ }^{[8]}$ Microscopic changes in acute appendicitis may vary from minimal focal inflammation to total wall necrosis. ${ }^{[9]}$

Cite this article as: Gökhan S, Aydın İE, Pamukçu Günaydın G, Yıldırım Ç, Tanrıverdi F, Gürü S, et al. Comparison of thiol/disulphide homeostasis with modified Alvarado and RIPASA scores in the diagnosis of acute appendicitis. Ulus Travma Acil Cerrahi Derg 2020;26:389-395.

Address for correspondence: İsmail Erkan Aydın, M.D.

Çankırı Devlet Hastanesi, Acil Servis Kliniği, Çankırı, Turkey

Tel: +90 376 - 2132727 E-mail: erkanaydinmd@gmail.com

Ulus Travma Acil Cerrahi Derg 2020;26(3):389-395 DOI: 10.14744/tjtes.2019.65II8 Submitted: 31.05.2019 Accepted: 27.12.2019 Online: 13.05.2020

Copyright 2020 Turkish Association of Trauma and Emergency Surgery 
The diagnosis of acute appendicitis may be delayed, and complications may occur despite physical examination, laboratory tests and imaging methods. ${ }^{[10,11]}$ Due to the presence of atypical symptoms, there is a confusion of appendicitis with urogenital diseases and its similarity with gynecological diseases in the elderly population, children, pregnant women and female patients. ${ }^{[1,12]}$ For these reasons, the researchers have worked on new parameters, including oxidative stress markers, to diagnose the afore-said disease more clearly, and they have improved the diagnostic scoring systems.

Although the pathophysiology of acute appendicitis is generally known, the factors playing a role in its development are still being investigated. The probable role of some oxidative stress markers in the development of inflammation and the occurrence and diagnosis of acute appendicitis has been investigated in various studies. ${ }^{[9,13,14]}$ Thiol/disulfide homeostasis has a significant place in antioxidant protection, signal transduction and detoxification in addition to the maintenance of enzyme activities and transcriptional factors and apoptosis. $[15,16]$ Disruptions are seen in these vital cellular functions in the process of abnormal thiol/disulfide homeostasis. Pathologies are observed in organelles because of the oxidative stress, which results in imbalances. ${ }^{[15]}$ It has been indicated in the literature that the disruption of thiol/disulfide homeostasis plays a significant role in the inflammation-causing the diseases. ${ }^{[17,18]}$

The Modified Alvarado and RIPASA (The Raja Isteri Pengiran Anak Saleha Appendicitis) scorings (Table I and Table 2) are two important scoring systems used for the diagnosis of acute appendicitis, and these scoring systems are utilized for ensuring a rapid and accurate diagnosis. ${ }^{[1,6]}$

In this study, we aimed to investigate the role of thiol/disulfide homeostasis parameters, a current oxidative stress marker, in the diagnosis of acute appendicitis and the impacts of the relationship between the oxidative stress and two important scoring systems on the development and diagnosis of acute appendicitis.

Table I. Modified Alvarado scale ${ }^{[19]}$

\begin{tabular}{lc}
\hline Manifestations & Value \\
\hline Symptoms & \\
$\quad$ Migration of pain & $\mathrm{I}$ \\
$\quad$ Anorexia & $\mathrm{I}$ \\
$\quad$ Nausea and/or vomiting & $\mathrm{I}$ \\
Signs & \\
$\quad$ Right Lower Quadrant tenderness & 2 \\
$\quad$ Rebound & $\mathrm{I}$ \\
$\quad$ Elevated temperature & $\mathrm{I}$ \\
Laboratory values & \\
$\quad$ Leukocytosis & 2 \\
\hline
\end{tabular}

Table 2. RIPASA score ${ }^{[19]}$

\begin{tabular}{lc}
\hline Parameters & Score \\
\hline Female & 0.5 \\
Male & 1.0 \\
Age $>40$ years & 0.5 \\
Age $<39.9$ years & 1.0 \\
Right iliac fossa pain & 0.5 \\
Migration of pain to right iliac fossa & 0.5 \\
Anorexia & 1.0 \\
Nausea and vomiting & 1.0 \\
Duration of symptoms $<48$ hours & 1.0 \\
Duration of symptoms $>48$ hours & 0.5 \\
Right iliac fossa tenderness & 1.0 \\
Guarding & 2.0 \\
Rebound tenderness & 1.0 \\
Rovsing's sign & 2.0 \\
Fever & 1.0 \\
Raised white blood cell & 1.0 \\
Negative urine analysis & 1.0 \\
Total score & 16.5 \\
\hline
\end{tabular}

RIPASA: The Raja Isteri Pengiran Anak Saleha Appendicitis.

\section{MATERIALS AND METHODS}

\section{Study Design and Participants}

The approval was obtained from the Ethics Committee of the Faculty of Medicine at Ankara Yıldırım Beyazıt University in accordance with the latest version of the Declaration of Helsinki. A prospective study was carried out on 265 patients who were admitted to the Emergency Department of Atatürk Training and Research Hospital affiliated to the Faculty of Medicine at Ankara Yıldırım Beyazıt University with the complaint of right lower quadrant pain between 01.07 .2017 and 3I.12.2017, and they were followed up with the pre-diagnosis of acute appendicitis. Out of 265 patients, 97 were diagnosed with acute appendicitis (Group I), and the remaining 168 patients were classified as the group without appendicitis (Group 2).

Acute appendicitis was diagnosed using laboratory tests and imaging methods, such as ultrasonography and computed tomography, as well as the clinical symptoms and physical examination. Standard study forms were filled with necessary information about the patients taking part in this study, such as their age, sex, complaints, medical history, concomitant system findings and diseases, signs and symptoms at the moment of admission to the emergency department (abdominal tenderness-rebound-defense, nausea-vomiting, high fever, loss of appetite, and location and dissemination of the pain), laboratory findings, imaging results, operation notes about the 
patients undergoing a surgical procedure, and histopathology results. The patients having a chronic disease, the individuals using any substance or drug, the ones suffering from any serious trauma in the recent year and undergoing appendectomy procedure before, pregnant women and the patients under the age of 18 were excluded from this study.

\section{Biochemical Analysis}

We asked the participants to give venous blood samples for the measurement of thiol/disulfide homeostasis parameters. Then, we centrifuged the blood samples of the patients at $1500 \mathrm{rpm}$ for ten minutes, and we separated the plasma and serum samples. We stored the serum samples at $-80^{\circ} \mathrm{C}$ until the collection of all samples. In the following phase, we sent the plasma samples that were analyzed concerning thiol/disulfide levels to the biochemical laboratory at Atatürk Training and Research Hospital, Ankara, Turkey, subsequent to the completion of the sample collection process.

The levels of thiol/disulfide homeostasis have been measured using a one-sided test since $1979 ;{ }^{[20]}$ however, the new method developed by Erel and Neşelioğlu has enabled the separate and collective measurement of both variables. ${ }^{[15]}$

The laboratory staff measured the native thiol and total thiol using a new and fully automatic system, and they calculated the ratios of disulfide, disulfide/native thiol, disulfide/total thiol and native thiol/total thiol (ErelNeselioglu). ${ }^{[15]} \mathrm{A}$ novel automated method with an automated analyzer was used for the performance of serum thiol-disulfide profile tests (Cobas 50I, Roche, Mannheim, Germany). The personal information of the laboratory staff carrying out the measurement analysis on the plasma thiol/disulfide homeostasis was kept confidential, and it was not indicated in the patients' clinical information and outcome. The treating physicians, study staff, or investigators were not informed about the results during the study period.

\section{Scoring Systems}

Modified Alvarado scores of the patients (Table I) were calculated, and the patients were classified as the high-risk group for 7 or higher scores and the low-risk group for the scores below $7{ }^{[21,22]}$ At the same time, the Ripasa scores of the patients (Table 2) were calculated, and the patients were classified as the high-risk group for 7.5 or higher scores and the low-risk group for the scores below 7.5. ${ }^{[22,23]}$ Thiol, disulfide, disulfide/native thiol, disulfide/total thiol and native thiol/total thiol values were evaluated both in group $I$ and group 2 and in the high-risk group and the low-risk group determined through the Modified Alvarado and Ripasa scores.

\section{Statistical Analysis}

The results were given as mean $\pm S D$. Univariate statistical analyses were performed using the chi-square test for categorical variables and student's t-test for continuous variables. $\mathrm{P}<0.05$ was accepted to be statistically significant.

\section{RESULTS}

Out of 265 patients included in this study, $60.8 \%$ were male $(n=161)$, and $39.2 \%$ were female $(n=104)$. The mean age of the patients was $32.45 \pm 12.19$ years. Male population in Group I was $74.2 \%(n=72)$ and female population was $25.8 \%(n=25)$. The mean age of the patients was $32.84 \pm 12.75$ years. $53 \%$ of Group 2 was represented by the male population $(n=89)$ and this percentage was $47 \%$ for female patients $(n=79)$, and the mean age of the patients in this group was $32.23 \pm 11.89$ years. There was no statistically significant difference between group I and group 2 concerning age; however, the higher number of the male patients in group I was found to be significant $(p=0.702, p=0.001$, respectively).

When group I was compared with group 2 according to the Thiol/Disulfide homeostasis parameters, the mean values of disulfide, disulfide/native thiol and disulfide/total thiol were

Table 3. Comparison of the Group I and Group 2 in concerning Thiol/Disulfide homeostasis parameters, Ripasa and Modified Alvarado scorings

\begin{tabular}{|c|c|c|c|}
\hline & Group I $(n=97)$ & Group $2(n=168)$ & $\mathbf{p}$ \\
\hline & Mean $\pm S D$ & Mean $\pm S D$ & \\
\hline Native thiol $(\mu \mathrm{mol} / \mathrm{L})$ & $411.89 \pm 89.18$ & $449.29 \pm 61.47$ & $<0.001$ \\
\hline Total thiol $(\mu \mathrm{mol} / \mathrm{L})$ & $464.12 \pm 81.01$ & $495.49 \pm 64.46$ & 0.001 \\
\hline Disulfide $(\mu \mathrm{mol} / \mathrm{L})$ & $29.11 \pm 15.32$ & $22.08 \pm 10.50$ & $<0.001$ \\
\hline Disulfide/native thiol & $0.082 \pm 0.078$ & $0.050 \pm 0.026$ & $<0.001$ \\
\hline Disulfide/total thiol & $0.065 \pm 0.040$ & $0.045 \pm 0.022$ & $<0.001$ \\
\hline Native thiol/total thiol & $0.878 \pm 0.092$ & $0.907 \pm 0.062$ & 0.007 \\
\hline RIPASA score & $10.02 \pm 2.36$ & $6.93 \pm 1.71$ & $<0.001$ \\
\hline Modified Alvarado score & $6.28 \pm 1.40$ & $4.18 \pm 1.56$ & $<0.001$ \\
\hline
\end{tabular}

RIPASA: The Raja Isteri Pengiran Anak Saleha Appendicitis; SD: Standard deviation. 
determined to be significantly higher in group I $(p<0.00 \mathrm{I})$, and the mean values of native thiol, total thiol and native thiol/ total thiol were found to be significantly lower in the same group ( $<<0.00 \mathrm{I}, 0.00 \mathrm{I}$ and 0.007 , respectively). Thiol/Disulfide homeostasis parameters of both groups are given in Table 3.

When the high-risk group and the low-risk group determined using Ripasa scoring were compared to each other in accordance with Thiol/Disulfide homeostasis parameters, the mean values of disulfide, disulfide/native thiol and disulfide/ total thiol were found to be significantly higher in the highrisk group ( $p=0.016,0.003$ and 0.001 , respectively) while the mean values of native thiol and total thiol were detected to be significantly lower in the same group $(p=0.006$ and 0.003 , respectively). There was no significant difference between the groups concerning native thiol/total thiol ratios $(p=0.386)$. Thiol/Disulfide homeostasis parameters of the high-risk group and the low-risk group determined through Ripasa scoring are given in Table 4.

When the high-risk group and the low-risk group determined through the modified Alvarado scoring were compared to each other according to Thiol/Disulfide homeostasis parameters, it was found out that the mean values of native thiol and total thiol were significantly higher in the low-risk group $(p=0.043$ and 0.039 , respectively). On the other hand, no significant difference was recorded between two groups concerning the mean values of disulfide, disulfide/native thiol, disulfide/ total thiol and native thiol/total thiol. Table 5 shows the Thiol/ Disulfide homeostasis parameters of the high risk and low-risk groups according to the modified Alvarado scoring.

\section{DISCUSSION}

Acute appendicitis is the most common cause of abdominal pain requiring surgical intervention worldwide, and it is a surgical pathology associated with inflammatory responses. ${ }^{[8,24]}$ Clinic history and physical examination are the most important points in the diagnosis of acute appendicitis. On the other hand, numerous methods including laboratory tests, ultrasonography and computed tomography, are used to diagnose acute appendicitis correctly. ${ }^{[25,26]}$ Despite all these techniques, the rate of misdiagnosis is considerably high. For these reasons, the correct diagnosis of acute appendicitis is regarded as a considerable challenge for physicians in today's world. The development of specific tests for the diagnosis of acute appendicitis and the use of scoring systems, such as the Modified Alvarado and RIPASA, will not only prevent unnecessary surgical interventions but also result in a decrease

Table 4. Comparison of thiol/disulfide homeostasis parameters according to RIPASA scoring

\begin{tabular}{|c|c|c|c|}
\hline & High risk $(n=144)$ & Low risk $(n=121)$ & $\mathbf{p}$ \\
\hline & Mean $\pm S D$ & Mean $\pm S D$ & \\
\hline Native thiol $(\mu \mathrm{mol} / \mathrm{L})$ & 424. $18 \pm 79.45$ & $449.18 \pm 66.88$ & 0.006 \\
\hline Total thiol $(\mu \mathrm{mol} / \mathrm{L})$ & $471.99 \pm 73.33$ & $498.32 \pm 68.92$ & 0.003 \\
\hline Disulfide $(\mu \mathrm{mol} / \mathrm{L})$ & $26.36 \pm 14.13$ & $22.62 \pm 11.01$ & 0.016 \\
\hline Disulfide/native thiol & $0.070 \pm 0.067$ & $0.05 I \pm 0.027$ & 0.003 \\
\hline Disulfide/total thiol & $0.058 \pm 0.036$ & $0.046 \pm 0.023$ & 0.001 \\
\hline Native thiol/total thiol & $0.893 \pm 0.091$ & $0.901 \pm 0.052$ & 0.386 \\
\hline
\end{tabular}

RIPASA: The Raja Isteri Pengiran Anak Saleha Appendicitis; SD: Standard deviation.

Table 5. Comparison of thiol/disulfide homeostasis parameters according to the modified Alvarado scoring

\begin{tabular}{lcccc}
\hline & High risk $(\mathbf{n = 5 8})$ & & Low risk $(\mathbf{n = 2 0 7})$ & p \\
\cline { 2 - 3 } & Mean \pm SD & & Mean \pm SD & \\
\hline Native thiol $(\mu \mathrm{mol} / \mathrm{L})$ & $417.15 \pm 78.62$ & & $440.77 \pm 73.17$ & 0.043 \\
Total thiol $(\mu \mathrm{mol} / \mathrm{L})$ & $465.85 \pm 75.58$ & & $489.10 \pm 70.86$ & 0.039 \\
Disulfide $(\mu \mathrm{mol} / \mathrm{L})$ & $26.58 \pm 13.58$ & & $24.11 \pm 12.70$ & 0.219 \\
Disulfide/native thiol & $0.069 \pm 0.053$ & & $0.059 \pm 0.053$ & 0.214 \\
Disulfide/total thiol & $0.059 \pm 0.037$ & & $0.050 \pm 0.029$ & 0.112 \\
Native thiol/total thiol & $0.893 \pm 0.087$ & & $0.898 \pm 0.072$ & 0.703 \\
\hline
\end{tabular}

SD: Standard deviation. 
in morbidity and mortality due to the possibility of early diagnosis. ${ }^{[14,21]}$ Recently, the researchers have studied on many markers, such as oxidative stress markers and inflammatory markers, primarily to improve the diagnosis of acute appendicitis. $^{[8,13,27-29]}$

Our study has indicated higher incidence rate of acute appendicitis in male patients in conformity with the literature. ${ }^{[30,31]}$ In our study, the number of male patients was recorded to be higher than the women's number both in the general patient population included in this study and in the group suffering from acute appendicitis. At the same time, the number of males was higher than females in the group with acute appendicitis. This medical condition is mostly observed in young adults, and the peak incidence of the disease is especially recorded in the second and third decades. ${ }^{[32]}$ While there was no significant relationship between the sex and age of our patients, the age range was found to be compatible with the literature. ${ }^{[31,33]}$

Yildirim et al. ${ }^{[34]}$ reported in their study on the verification of the diagnosis of acute appendicitis that the inflammatory markers were elevated and that they could be used in the process. In another study carried out by Ozan et al.,. ${ }^{[35]}$ the inflammation markers were seen to increase in acute appendicitis. Yilmaz et al. ${ }^{[36]}$ stated that oxidative stress showed an increase in acute appendicitis. Dumlu et al..$^{[9]}$ performed a study on the oxidative stress markers, including serum and total thiol levels in the tissues in acute appendicitis by analyzing the serum and tissue samples, and they demonstrated that the afore-said levels were different in the patients with acute appendicitis when compared to the control group. In the results of the same study, Dumlu et al. ${ }^{\left[{ }^{[9]}\right.}$ remarked that the balance between oxidant and antioxidant defense systems may influence the pathogenesis of acute appendicitis and that the changes on the levels of oxidative stress markers may also play a role in acute appendicitis. It has been indicated in the literature that an increase in disulfide levels and a decrease in thiol levels are expected in the event of oxidative stress. ${ }^{[14,15,37]}$

Dumlu et al. ${ }^{[9]}$ reported in their study that total thiol levels were lower in the group with acute appendicitis than the control group. Similar to the study carried out by Dumlu et al., Yilmaz et al. ${ }^{[36]}$ also found out that the thiol levels showed a decrease in the cases of acute appendicitis. In another study in which thiol/disulfide homeostasis was measured through a new method developed by Erel and Neselioglu, ${ }^{[15]}$ Ozyazici et al. ${ }^{[14]}$ showed that native thiol, total thiol and native thiol/total thiol levels were significantly lower in the patient group with acute appendicitis when compared to the control group and that the disulfide, disulfide/native thiol and disulfide/total thiol levels were higher in the same group. In the study performed by Elmas et al., ${ }^{[38]}$ disulfide levels and disulfide/native thiol and disulfide/total thiol ratios were found to be higher in the patients with acute appendicitis while native thiol, total thiol and native thiol/total thiol levels were lower in the same group.
In our study, disulfide levels and disulfide/native thiol and disulfide/total thiol ratios were measured to be higher in the group with acute appendicitis, which was compatible with the studies in the literature. Also, other infectious and inflammatory conditions may impair thiol-disulphide homeostasis. Disulfide/native thiol and disulfide/total thiol ratios are high at these conditions. ${ }^{[39-41]}$ Similarly, native thiol and total thiol levels as well as native thiol/total thiol ratio were found to be lower in the group with acute appendicitis. In the light of the results obtained from both our research and previous studies, it can be said that the oxidative stress and the impairment of the balance between oxidant and antioxidant systems may play a role in the pathogenesis of acute appendicitis.

The Alvarado and Modified Alvarado scoring systems, which are popularly used for the diagnosis of acute appendicitis, have effective sensitivity and specificity, especially for western societies. ${ }^{[42,43]}$ The RIPASA scoring has recently emerged as an important scoring system with more sensitivity, specificity and diagnostic accuracy than the Alvarado scoring system, especially for Asian populations. ${ }^{[1,22]}$ In our study, both the Alvarado and the RIPASA scores were found to be higher in the group with acute appendicitis, which is compatible with the studies in the literature. ${ }^{[19]}$

There are a limited number of studies in the literature showing the relationship between the scoring systems and inflammatory markers in the diagnosis of acute appendicitis. ${ }^{[4-46]}$ In the study carried out by Zouari et al., ${ }^{[47]}$ it was indicated that there was no difference between the single-use of Alvarado score and the combined utilization of Alvarado and CRP concerning predictive values in the diagnosis of acute appendicitis. Jung et al. ${ }^{[44]}$ reported in their study that Appendicitis Inflammatory Response (AIR) score did not create a significant difference in the distinction between perforated and non-perforated appendicitis in elderly patients, but that the modified AIR score obtained through the combination with Neutrophile-to lymphocyte count ratio may be significant for making a distinction between perforated and non-perforated acute appendicitis risks in elderly patients.

According to our literature review, to our knowledge, there is no study showing the correlation between thiol/disulfide homeostasis and the RIPASA and Modified Alvarado scores used in the diagnosis of acute appendicitis. In our study, the mean values of disulfide, disulfide/native thiol and disulfide/ total thiol were found to be higher in the patients with a high risk of acute appendicitis according to RIPASA score, while the mean values of native thiol and total thiol were calculated to be lower in the same group. In accordance with the modified Alvarado score, the mean values of native thiol and total thiol were found to be higher in the low-risk group. On the other hand, no difference was recorded between two groups concerning the mean values of disulfide, disulfide/native thiol, disulfide/total thiol and native thiol/total thiol. High values of disulfide, disulfide/native thiol, and disulfide/total thiol in the 
high-risk group determined through RIPASA scoring in the case of acute appendicitis are one of the most outstanding results of our study, and we think that the combined use of the above-mentioned methods may be beneficial for the diagnosis of acute appendicitis. Similarly, we also believe that the detection of high mean values of native thiol and total thiol in the patients with low risk, according to Alvarado scoring, would be useful concerning the follow-up and discharge process of the patients.

To our knowledge, our research is the first study in the literature that has analyzed the scoring systems and thiol/ disulfide homeostasis parameters that are oxidative stress markers and comparing these two components in the diagnosis of acute appendicitis. The measurement of thiol/disulfide homeostasis parameters, which are readily available and cheap oxidative stress indicators, can be used as an effective biochemical marker in acute appendicitis. Consequently, the combined use of thiol/disulfide homeostasis parameters and RIPASA and modified scoring systems may facilitate the diagnosis of acute appendicitis.

Ethics Committee Approval: Approved by the local ethics committee.

\section{Peer-review: Internally peer-reviewed.}

Authorship Contributions: Concept: S.G., I.E.A., G.P.G.; Design: S.G., I.E.A., G.P.G.; Supervision: S.G., F.T., Ö.E.; Fundings: S.G., İ.E.A., Ö.E.; Materials: Ç.Y., F.T., S.G.; Data: İ.E.A., S.G., F.A.K.; Analysis: S.G., G.P.G., Ö.E.; Literature search: I.E.A., G.P.G., Ç.Y.; Writing: S.G., G.P.G., Ç.Y.; Critical revision: S.G., F.T., F.A.K., Ö.E.

\section{Conflict of Interest: None declared.}

Financial Disclosure: The authors declared that this study has received no financial support.

\section{REFERENCES}

1. Chong CF, Adi MI, Thien A, Suyoi A, Mackie AJ, Tin AS, et al. Development of the RIPASA score: a new appendicitis scoring system for the diagnosis of acute appendicitis. Singapore Med J 2010;51:220-5.

2. Quick CRG, Reed JB, Harper SJ, Saeb-Parsy K. Essential surgery: Problems, diagnosis and management: With student consult Online Access. Lincoln, UK: Churchill Livingstone; 2013.

3. Addiss DG, Shaffer N, Fowler BS, Tauxe RV. The epidemiology of appendicitis and appendectomy in the United States. Am J Epidemiol 1990;132:910-25. [CrossRef]

4. Nshuti R, Kruger D, Luvhengo TE. Clinical presentation of acute appendicitis in adults at the Chris Hani Baragwanath academic hospital. Int J Emerg Med 2014;7:12. [CrossRef]

5. Memon ZA, Irfan S, Fatima K, Iqbal MS, Sami W. Acute appendicitis: diagnostic accuracy of Alvarado scoring system. Asian J Surg 2013;36:144-9. [CrossRef]

6. Kalan M, Talbot D, Cunliffe WJ, Rich AJ. Evaluation of the modified Alvarado score in the diagnosis of acute appendicitis: a prospective study. Ann R Coll Surg Engl 1994;76:418-9.

7. Rao PM, Rhea JT, Novelline RA. Helical CT of appendicitis and diverti- culitis. Radiol Clin North Am 1999;37:895-910. [CrossRef]

8. de Oliveira Machado SL, Bagatini MD, da Costa P, Baldissarelli J, Reichert KP, de Oliveira LS, et al. Evaluation of mediators of oxidative stress and inflammation in patients with acute appendicitis. Biomarkers 2016;21:530-7. [CrossRef]

9. Dumlu EG, Tokaç M, Bozkurt B, Yildirim MB, Ergin M, Yalçin A, et al. Correlation between the serum and tissue levels of oxidative stress markers and the extent of inflammation in acute appendicitis. Clinics (Sao Paulo) 2014;69:677-82. [CrossRef]

10. Dado G, Anania G, Baccarani U, Marcotti E, Donini A, Risaliti A, et al. Application of a clinical score for the diagnosis of acute appendicitis in childhood: a retrospective analysis of 197 patients. J Pediatr Surg 2000;35:1320-2. [CrossRef]

11. Paulson EK, Kalady MF, Pappas TN. Clinical practice. Suspected appendicitis. N Engl J Med 2003;348:236-42. [CrossRef]

12. Gilmore OJ, Browett JP, Griffin PH, Ross IK, Brodribb AJ, Cooke TJ, et al. Appendicitis and mimicking conditions. A prospective study. Lancet 1975;2:421-4. [CrossRef]

13. Ozdogan M, Devay AO, Gurer A, Ersoy E, Devay SD, Kulacoglu H, et al. Plasma total anti-oxidant capacity correlates inversely with the extent of acute appendicitis: a case control study. World J Emerg Surg 2006;1:6.

14. Ozyazici S, Karateke F, Turan U, Kuvvetli A, Kilavuz H, Karakaya B, et al. A Novel Oxidative Stress Mediator in Acute Appendicitis: Thiol/ Disulphide Homeostasis. Mediators Inflamm 2016;2016:6761050.

15. Erel O, Neselioglu S. A novel and automated assay for thiol/disulphide homeostasis. Clin Biochem 2014;47:326-32. [CrossRef]

16. Circu ML, Aw TY. Reactive oxygen species, cellular redox systems, and apoptosis. Free Radic Biol Med 2010;48:749-62. [CrossRef]

17. Matteucci E, Giampietro O. Thiol signalling network with an eye to diabetes. Molecules 2010;15:8890-903. [CrossRef]

18. Kundi H, Ates I, Kiziltunc E, Cetin M, Cicekcioglu H, Neselioglu S, et al. A novel oxidative stress marker in acute myocardial infarction; thiol/ disulphide homeostasis. Am J Emerg Med 2015;33:1567-71. [CrossRef]

19. Shuaib A, Shuaib A, Fakhra Z, Marafi B, Alsharaf K, Behbehani A. Evaluation of modified Alvarado scoring system and RIPASA scoring system as diagnostic tools of acute appendicitis. World J Emerg Med 2017;8:276-80. [CrossRef]

20. Ellman G, Lysko H. A precise method for the determination of whole blood and plasma sulfhydryl groups. Anal Biochem 1979;93:98-102.

21. Singla A, Singla S, Singh M, Singla D. A comparison between modified Alvarado score and RIPASA score in the diagnosis of acute appendicitis. Updates Surg 2016;68:351-5. [CrossRef]

22. Chong CF, Thien A, Mackie AJ, Tin AS, Tripathi S, Ahmad MA, et al. Comparison of RIPASA and Alvarado scores for the diagnosis of acute appendicitis. Singapore Med J 2011;52:340-5.

23. Malik MU, Connelly TM, Awan F, Pretorius F, Fiuza-Castineira C, El Faedy O, et al. The RIPASA score is sensitive and specific for the diagnosis of acute appendicitis in a western population. Int J Colorectal Dis 2017;32:491-7. [CrossRef]

24. Graffeo CS, Counselman FL. Appendicitis. Emerg Med Clin North Am 1996;14:653-71. [CrossRef]

25. Pisano M, Coccolini F, Poiasina E, Bertoli P, Capponi Michela G, Poletti EM, et.al. Conservative treatment for uncomplicated acute appendicitis in adults. Emerg Med Health Care 2013;1:2. [CrossRef]

26. Ruffolo C, Fiorot A, Pagura G, Antoniutti M, Massani M, Caratozzolo E, et al. Acute appendicitis: what is the gold standard of treatment? World J Gastroenterol 2013;19:8799-807. [CrossRef]

27. Schellekens DHSM, Hulsewe KWE, van Acker BAC, van Bijnen AA, Jaegere TMH, Sastrowijoto $\mathrm{SH}$, et al. Evaluation of the diagnostic accu- 
racy of plasma markers for early diagnosis in patients suspected for acute appendicitis. Academic Emergency Medicine 2013;20:703-10. [CrossRef]

28. Kaya M, Boleken ME, Kanmaz T, Erel O, Yucesan S. Total antioxidant capacity in children with acute appendicitis. Eur J Pediatr Surg 2006;16:34-8. [CrossRef]

29. Satomi A, Hashimoto T, Murakami S, Murai H, Kawase H, Takahashi $\mathrm{S}$, et al.. Tissue superoxide dismutase (SOD) activity and immunohistochemical staining in acute appendicitis: correlation with degree of inflammation. J Gastroenterol 1996;31:639-45. [CrossRef]

30. Sato Y, Kojimahara N, Kiyohara K, Endo M, Yamaguchi N; Appendicitis study group of Mobi-kids Japan. Association between climatic elements and acute appendicitis in Japan. J Surg Res 2017;211:64-9. [CrossRef]

31. Kartal K, Yazıcı P, Ünlü TM, Uludağ M, Mihmanlı M. How to avoid negative appendectomies: Can US achieve this?. Ulus Travma Acil Cerrahi Derg 2017;23:134-8. [CrossRef]

32. Rybkin AV, Thoeni RF. Current concepts in imaging of appendicitis. Radiol Clin North Am 2007;45:411-vii. [CrossRef]

33. Hobeika C, Hor T, Chereau N, Laforest A, Bachmann R, Sourouille I, et al. Day Surgery for Acute Appendicitis in Adults: A Prospective Series of 102 Patients. Surg Laparosc Endosc Percutan Tech 2017;27:158-62.

34. Yildirim O, Solak C, Koçer B, Unal B, Karabeyoğlu M, Bozkurt B, et al. The role of serum inflammatory markers in acute appendicitis and their success in preventing negative laparotomy. J Invest Surg 2006;19:345-52. [CrossRef]

35. Ozan E, Ataç GK, Alişar K, Alhan A. Role of inflammatory markers in decreasing negative appendectomy rate: A study based on computed tomography findings. Ulus Travma Acil Cerrahi Derg 2017;23:477-82.

36. Yilmaz FM, Yilmaz G, Erol MF, Köklü S, Yücel D. Nitric oxide, lipid peroxidation and total thiol levels in acute appendicitis. J Clin Lab Anal 2010;24:63-6. [CrossRef]

37. Kundi H, Gok M, Cetin M, Kiziltunç E, Topcuoglu C, Neselioglu S, et.al. Association of thiol disulfide homeostasis with slow coronary flow. Scandinavian Cardiovascular J 2016;50:213-7. [CrossRef]
38. Elmas B, Yildiz T, Yazar H, İlçe Z, Bal C, Özbek B, et.al. New Oxidative Stress Markers Useful in the Diagnosis of Acute Appendicitis in Children: Thiol/Disulfide Homeostasis and the Asymmetric Dimethylarginine Level. Pediatr Emerg Care 2017 Nov 14. doi: 10.1097/ PEC.0000000000001339. [Epub ahead of print] [CrossRef]

39. Şimşek E, Bicer CK, Mazlumoğlu MR, Kara SS, Erel O, Çarlıŏlu A. Is otitis media with effusion associated with oxidative stress? Evaluation of thiol/disulfide homeostasis. Am J Otolaryngol 2019;40:164-7. [CrossRef]

40. Tuzcu A, Baykara RA, Omma A, Acet GK, Dogan E, Cure MC, et al. Thiol/Disulfide homeostasis in patients with rheumatoid arthritis. Rom J Intern Med 2019;57:30-6. [CrossRef]

41. Köseoğlu H, Alșşı M, Başaran M, Tayfur Yürekli Ö, Solakoğlu T, Tahtac1 M, et al. Dynamic thiol/disulphide homeostasis in acute pancreatitis. Turk J Gastroenterol 2018;29:348-53.

42. Alvarado A. A practical score for the early diagnosis of acute appendicitis. Ann Emerg Med 1986;15:557-64. [CrossRef]

43. Owen TD, Williams H, Stiff G, Jenkinson LR, Rees BI. Evaluation of the Alvarado score in acute appendicitis. J R Soc Med 1992;85:87-8.

44. Jung SK, Rhee DY, Lee WJ, Woo SH, Seol SH, Kim DH, et al. Neutrophil-to-lymphocyte count ratio is associated with perforated appendicitis in elderly patients of emergency department. Aging Clin Exp Res 2017;29:529-36. [CrossRef]

45. Andersson M, Andersson RE. The appendicitis inflammatory response score: a tool for the diagnosis of acute appendicitis that outperforms the Alvarado score. World J Surg 2008;32:1843-9. [CrossRef]

46. Khanafer I, Martin DA, Mitra TP, Eccles R, Brindle ME, Nettel-Aguirre A, et al. Test characteristics of common appendicitis scores with and without laboratory investigations: a prospective observational study. BMC Pediatr 2016;16:147. [CrossRef]

47. Zouari M, Jallouli M, Louati H, Kchaou R, Chtourou R, Kotti A, et al. Predictive value of $\mathrm{C}$-reactive protein, ultrasound and Alvarado score in acute appendicitis: a prospective pediatric cohort. Am J Emerg Med 2016;34:189-92. [CrossRef]

\title{
ORIJINAL ÇALIŞMA - ÖZET
}

\section{Akut apandisit tanısında tiyol/disülfit homeostazının modifiye Alvarado ve RIPASA skorları ile karşılaştırılması \\ Dr. Servan Gökhan, ${ }^{1}$ Dr. İsmail Erkan Aydın, ${ }^{2}$ Dr. Gül Pamukçu Günaydın, ${ }^{1}$ Dr. Çağdaş Yıldırım, ${ }^{1}$ Dr. Fatih Tanrıverdi, ${ }^{1}$ Dr. Selahattin Gürü, ${ }^{3}$ Dr. Fatih Ahmet Kahraman, ${ }^{1}$ Dr. Özcan Erel ${ }^{4}$}

\author{
'Yıldırım Beyazıt Üniversitesi Tıp Fakültesi, Acil Tıp Anabilim Dalı, Ankara \\ ${ }^{2}$ Çankırı Devlet Hastanesi, Acil Servis Kliniği, Çankırı \\ ${ }^{3}$ Bilkent Şehir Hastanesi, Acil Servis Kliniği, Ankara \\ ${ }^{4}$ Yıldırım Beyazıt Üniversitesi Tıp Fakültesi, Biyokimya Anabilim Dalı, Ankara
}

AMAÇ: Bu çalışma, akut apandisit tanısında tiyol/disülfit homeostaz parametrelerinin rolünü göstermeyi ve bu parametrelerin modifiye Alvarado ve RIPASA skorlama sistemleriyle birlikte kullanılmasının yararlı olup olmadığını belirlemeyi amaçlamaktadır.

GEREÇ VE YÖNTEM: Bu çalışma, acil servise 01.07.2017 ve 31.12.2017 tarihleri arasında sağ alt kadran ağrısı şikayeti ile başvuran ve çalışmanın dahil edilme kriterlerini karşılayan 265 hastada ileriye yönelik olarak gerçekleştirildi. Oksidatif stres belirteçleri iki grupta değerlendirildi. Bu parametrelerle modifiye Alvarado ve The Raja Isteri Pengiran Anak Saleha Appendicitis (RIPASA) skorlama sistemleri arasındaki ilişki analiz edildi.

BULGULAR: Apandisit grubunda ortalama disülfit, disülfit/native tiyol ve disülfit/total tiyol seviyeleri anlamlı olarak yüksek bulundu ( $p<0.00 \mathrm{I})$. Native tiyol, total tiyol ve native tiyol/total tiyol ortalamaları aynı grupta anlamlı olarak düşüktü (sırasıyla, $p<0.001,0.001$ ve 0.007 ). Ortalama disülfid, disülfid/native tiyol ve disülfid/total tiyol seviyelerinin RIPASA sonuçlarına göre yüksek riskli grupta anlamlı olarak yüksek olduğu saptanmıştır (sırasıla, $p=0.016,0.003$ ve 0.001 ).

TARTIŞMA: Tiyol/disülfit homeostaz parametreleri, akut apandisit tanısında modifiye Alvarado ve RIPASA skorlama sistemleriyle birlikte kullanılabilir.

Anahtar sözcükler: Akut apandisit; modifiye Alvarado ve RIPASA; tiyol/disülfit homeostazı.

Ulus Travma Acil Cerrahi Derg 2020;26(3):389-395 doi: 10.14744/tjtes.2019.65I I8 